\title{
Monetary Policy in a Systemic Crisis ${ }^{1}$
}

\author{
Xavier Freixas
}

\section{Universitat Pompeu Fabra and CEPR}

Tuesday, 10 November 2009

\section{Summary}

This paper examines the monetary policy followed during the current financial crisis from the perspective of the theory of the lender of last resort. It is argued that standard monetary policy measures would have failed because the channels through which monetary policy is implemented depend upon the well functioning of the interbank market. As the crisis developed, liquidity vanished and the interbank market collapsed, central banks had to inject much more liquidity at low interest rates than predicted by standard monetary policy models. At the same time, as the interbank market did not allow for the redistribution of liquidity among banks, central banks had to design new channels for liquidity injection.

\section{Introduction}

The recent collapse of the banking and financial system has raised fundamental issues regarding the fragility of financial markets its institutions, as well as the regulatory framework that intends to preserve its stability. The objective of this paper is to consider the key role central banks have had in avoiding a complete financial meltdown. Yet, to do so, central banks had to reinvent themselves in their role and modify the conduct of monetary policy as well as their lender of last resort responsibilities. We argue that, given the key role of liquidity in the development and propagation of the crisis, the classic lender of last resort

\footnotetext{
${ }^{1}$ We are grateful to Isabel Cairo, Adriana Nieto, David Vine and two anonymous referees for their comments. The usual disclaimer applies. We acknowledge funding from Spanish Ministry MICINN ECO2008-03066 and Generalitat de Catalunya 2002 DPRIR 00039.
} 
approach, of lending against good collateral at a penalty rate would have been a dramatic mistake. It was necessary to execute a number of "aggressive and creative policy actions" to quote Bernanke's own words (Bernanke, 2009). Indeed, since the beginning of the crisis, we have witnessed how central banks have been violating all standard monetary policy rules. Yet, by so doing, they have provided banks with a wide access to liquidity and have possibly avoided a complete gridlock of the banking industry. From an analytical perspective, there are two main questions to be considered when trying to assess central banks intervention. First, what is the role of liquidity in the current crisis, and how can monetary policy affect financial stability? Second, what theoretical arguments support the unconventional monetary policy central banks have followed? The current crisis has revealed both the key role of liquidity and the critical role of central banks as liquidity managers. This has turned upside down not only the conventional view regarding the separation between monetary policy and prudential regulation, but also the conventional wisdom of central banks lending only against perfectly safe collateral. We argue that models of asymmetric information and coordination help us to understand why the standard instruments of monetary policy would have been powerless to cope with the current crisis.

Our paper will be organized as follows: first we will briefly review the major driving forces in the current crisis, focusing specifically on the liquidity dimension of the contagion mechanisms at work. We will then turn to the behaviour of central banks when confronted with this crisis, and summarize the main characteristics of their interventions. In section 3 we will review the implications of the theories of the lender of last resort and contrast them with the recent central banks' interventions.

\section{The Crisis Environment}

To begin with, it is convenient to reject the usual view of the crisis as a new type of crisis. Of course, we must acknowledge the current crisis is unprecedented in terms of the complexity of existing financial instruments, because of its global dimension, and because its epicentre was in the US, something that hadn't happen since 1929. However, if we refer to the standard definition of a systemic crisis, that is, a crisis threatening the whole banking industry, we are bound to acknowledge that it counts with its three classical components: macroeconomic fragility, contagion and a trigger (De Bandt, O. and P.Hartmann, 2002). We will structure our discussion of the crisis by referring to these three components, emphasizing the major differences with previous crisis, and, in particular, the specific characteristics of the 
contagion mechanism. We will argue that the liquidity dimension had a tremendous impact in amplifying the crisis and, consequently, that monetary policy was of key importance as one of the major vehicles downsizing the effect of the liquidity shortage. Although the contagion effects have been the more spectacular, complex and noteworthy characteristics of the current crisis, in our view the initial driving force comes from the macroeconomic environment and it is therefore necessary to consider it first.

\subsection{Macroeconomic Fragility}

If we try to point to a unique ultimate cause for the crisis, two main views prevail.

On the one hand, the diagnosis of the Geneva report ${ }^{2}$ is that the main cause lies in market dynamics and the amplifying mechanisms that various market innovations had created. As its authors put it: "Thus we believe that financial crises are predominantly caused by market dynamics, not just by external shocks, though such shocks, e.g. the downturn in the US housing market in 2006, the quadrupling of oil prices in 1973/74, the stock market collapse in 1929, may well have been the trigger" (Brunnermeier et al., p.5). This standpoint is consistent with the view that the opacity of financial instruments was the main cause of the crisis, as argued by Gorton (2008). Thus the market dynamics view of the crisis considers that ultimate causes the role played by financial innovation that led banks to hold opaque assets that at some point became "toxic" and made any bank suspect of being insolvent. Once confidence in banks solvency vanished, access to liquidity disappeared and the crisis developed in a snowball effect.

The alternative view is that the ultimate cause for the current crisis lies in exuberant expectations and its effect on asset valuation.

Real estate and financial asset bubbles, defined as upward deviations from an asset's fundamental value, set the scene for the crisis: when these bubbles burst, this led to the collapse of the market for all related financial instruments (Asset back securities, Collateralized debt obligations...), the increase of uncertainty and the lack of confidence that caused the crisis. These bubbles built up partly because of the success of monetary policy in channelling liquidity to the markets, keeping inflation at bay and stimulating growth through low nominal interest rates. Yet this period of "great moderation", caused the overvaluation of

\footnotetext{
${ }^{2}$ This is an annual report launched by the International Center for Monetary and Banking Studies (ICMB) and CEPR where top academics and professionals survey the main facts and trends of world economy. The 2008 report offers a rigorous and synthetic perspective on the current crisis authored by Markus Brunnermeier, Andrew Crockett, Charles Goodhart, Avinash D. Persaud, Hyun Shin (2009).”
} 
assets which let to the crisis. Low interest rates and a lax liquidity injection policy, jointly with exuberant expectations for an ever increasing price of housing, led to an excessive growth of credit, an actual increase in relative real estate prices and overpriced financial assets. The low interest rates and credit expansion were sustainable because of the international distribution of savings that was characterized by fundamental imbalances. This point has been heavily emphasized in connection with the China's trade balance surplus investment in US financial assets. This recycling of China's savings in the US resulted in the stability of the exchange rate between these two countries that, in turn, facilitated the maintenance of China's trade balance surplus.

It is my argument that, although the asset valuation perspective on the crisis is much less of an intellectual challenge, as it implies that the crisis is not different from all other crises in the XXth century, there are three reasons why this traditional view may be a better explanation.

First, in some countries like Ireland and Spain, that are facing a spectacular banking crisis, financial innovations were practically non-existent.

Second, the opaque financial assets were traded in liquid markets before the crisis, so their opacity was inconsequential prior to July 2007. Of course, change of market sentiment as self-fulfilled prophecies could explain the switch from investors perceiving these assets as safe to their seeing them as "toxic". Yet it is suspicious that this occurs precisely when the number of loan delinquencies explodes thus making clear the existence of a bubble in real estate.

Third, the decrease in the volume of credit supports bubble bursting hypothesis but is not directly related to the market dynamics. This decrease could be the result of either a decrease in the demand for credit or a reduction in the supply of credit, as credit standards become more lax during an upturn and become stricter at the beginning of a downturn, in such a way that a strengthening in the lending standards precedes the actual downturn (Lown and Morgan, 2006).

As it is obvious, in the same way a lax credit policy generates a bubble, it is clear that the end of the credit supply expansion and a lower rate of growth for economic activity promotes its sudden burst. This effect is amplified by the same factors that intensify it during the expansionary phase of the cycle, as mentioned, banks' herding behaviour and credit procyclicality. In addition, the burst of the bubble interacts with the structures that financial innovations have imposed in this market, leading to an amplified effect. This means that 
instead of the market reacting to under pricing of risk through a price adjustment, it collapses because information asymmetries grow above sustainable levels.

\subsection{The channels of contagion}

As mentioned before, one of the characteristics of the banking industry is that the failure of one bank generates a negative externality on the solvency ${ }^{3}$ of others. This fragility of the banking industry is related to the liquidity insurance function of banks that invest in illiquid assets while offering liquid demand deposits. One of the particularities of the current crisis is that the channels of contagion at work are different from the classical ones, as liquidity played a key role in contagion, not only within the banking industry but also by propagating to new types of non-banking institutions, often referred to as "shadow banking". Consequently, we will refer to contagion as the impact the insolvency or liquidity shortage of one bank has on other banks liquidity and solvency. Instead, we will refer to amplifying mechanisms as the processes through which a macroeconomic phenomenon affecting the whole banking industry, such as a downturn or a decrease in asset prices is intensified. The distinction is indeed minor, and the boundaries between the two notions may be blurred, but it allow us to distinguish the impact of a liquidity and solvency problems in some institutions and the impact of macroeconomic and price.

\section{The Classical Contagion Mechanism}

The classical view of contagion mechanisms (see Freixas and Rochet, 2007) a systemic crisis considers two main contagion channels: contagion through the interbank network of reciprocal obligations and contagion through bank runs.

In its simplest version the first contagion mechanism implies that bankruptcy of bank A can trigger the bankruptcy of bank B because bank B is a large creditor of bank A and therefore there is a direct effect of the bankruptcy in generating losses in bank B. The complexities of the network of interbank lending, that is necessary for banks' efficient liquidity management, makes the mechanism more complex as each banks is a creditor of a number of other banks so that the solvency of each one may depend of the solvency of a the others. This interconnected network of banks claims have been well

\footnotetext{
${ }^{3}$ Here we refer to solvency either in perceived or effective terms.
} 
studied and Central banks have simulated the impact of a major bank bankruptcy or liquidity default on the other bank's balance sheet with the reassuring result that the potential losses generated by interbank lending (and not on the unforeseen potential risk for the interbank market to dry up) had a minor impact (Upper and Worms, 2004). This mechanism of direct contagion, based on the direct link through banks claims on each other, did not play a major role in the crisis, as quite often large banks were bailed out before reaching the bankruptcy stage. It may be argued that the Lehman bankruptcy was a major event on contagion, but its direct effect was limited when compared with its indirect effect.

Bank runs are characteristic of the banking industry as it results from the combination of illiquid assets and liquid deposits. Bank runs depend upon the coordination of depositors and are self-fulfilled prophecies because once a bank run start the best option for any depositor is to join the run.

Bank runs constitute a second type of contagion mechanism, already at work during the XIXth century. The reason for a bank run is the change in its short term debt holders' perception of the bank solvency, triggered by the financial distress of another bank. This may occur either because depositors anticipate other debt holders to run (speculative bank run), or because they assume a correlation between the value of the assets at the distressed bank and the value of their own bank's assets (fundamental bank run).

In today's financial environment, the mechanism of bank runs is not triggered by retail depositors as in the classical Diamond-Dybvig model, but by wholesale interbank depositors and large short-term claimholders. Two different reasons combine for this to be the case: first, banks holding a short-term claim on a bank close to financial distress not only have the incentives to follow the position of its counterpart but also have a better and faster access to relevant information on that bank's potential default; second, the existence of deposit insurance limit the incentives of depositors to acquire information on the bank and take the decision to withdraw its deposit. The recent case of Northern Rock is not an exception: although retail depositors did queue the bank, wholesale funding withdraw first, creating the bank's liquidity shortage.

Yet, apart from Northern Rock, we did not observe bank runs, and in any case they were not a vector of contagion, as Northern Rock was neither the result from nor caused the 
bankruptcy of any other bank. Contagion came from the liquidity shortage and its effect on investment banks' solvency as well as on financial markets, with its feed back effect on the banking industry liquidity and capital ratios.

\section{Liquidity driven contagion}

An asset is liquid if it is possible to make a making a transaction without this transaction causing a price change adverse to the trader, whether a buyer or a seller. The liquidity of an asset is an endogenous notion as it results from the choices of portfolio managers: buying an asset may become risky because agents predict it might be difficult to sell it later on. This is why in the present crisis, the illiquidity has gone from the subprime assets that were seen as possibly "toxic" to assets with more transparent cash flows (as standard corporate bonds), as their attractiveness decreased and that of cash and Treasury Bills increased.

Two simple mechanisms have been used by theoreticians to explain liquidity contagion, one based on a "cash in the market" approach and one that emphasizes "haircut spirals".

Cash in the market models allows a simple understanding of the mechanics of a liquidity shock and its transmission to the market, as the available liquidity is taken as exogenous. Under this assumption, a liquidity shortage will force banks to sell their assets. Still, the excess demand of liquidity will imply that the asset prices will drop. The argument goes as follows: as banks need have to raise a given amount of liquidity from the market, falling prices imply the banks are forced to liquidate more of their assets (fire sales). In other words, the banks demand for liquidity generates a backwards bending supply curve for securities: the lower the securities prices are, the higher the amount of the asset that will be sold and banks will thus be forced to sell at fire sale prices. This will continue until the banks themselves reduce their demand for liquidity, for instance by reducing their lending, or until the supply of liquidity increases as some other source of liquidity (Sovereign funds, mutual funds, pension funds,...) enter, the market, attracted by the low level of asset prices. The decrease in the price of assets may be considerable, as the demand for liquidity may be quite inelastic. Consequently, this will have a dramatic effect on the value of banks assets, and therefore on their solvency. 
The important point here is that, although some banks were not affected by liquidity shocks, the decrease in asset prices will affect them as well, thus generating a contagion effect from some banks liquidity squeeze to the rest of the industry.

The cash in the market model is a highly simplified approximation to the phenomena that occurred in the market in 2007 and 2008. Yet, when we consider, in addition, a number of more realistic views of the banking industry, we are forced to conclude that these additional features tend to aggravate the contagion mechanism from liquidity shortage to price decrease. We now proceed to consider these amplifying mechanisms.

First, banks cope with liquidity shocks not only by selling securities, but also by borrowing unsecured in the interbank market, so the liquidity shortage could have been solved by borrowing in the unsecured interbank market. In normal circumstances the interbank market would have allowed to cope with the liquidity shocks. Still, the existence of bubbles and the macroeconomic fragility led to a sudden stop of the unsecured interbank market for maturities beyond one day. The liquidity drought came as a surprise, and forced banks to sell their assets at fire prices. With a level of asymmetric information and a lower risk of dealing with a bank holding "toxic assets" would have increased interbank market spreads and allowed banks to operate some trade-off between the higher cost of interbank market borrowing and the higher cost of selling securities. Yet this was not the case and a "no transaction market" equilibrium à la Akerlof prevailed. Institutions in search of liquidity had then to fire-sell other assets.

Second, it could be argued that central banks injection of liquidity at the aggregate level, through riskless loans could have solved the problem. Yet, the magnitude of financial institutions' liquidity needs exceeded the amount of T-bills they were holding. Injecting additional liquidity would have meant for central banks to take risks and buy toxic assets, but this would have been a generalized bail-out of financial institutions, something that was clearly beyond central banks mandate and could only be achieve in cooperation with the Treasury. It could be argued that, at least partially, this liquidity injection could come from the agents that were demanding liquidity and that are now reinvesting it in other parts of the financial system, e.g. if they withdraw their deposits but invest in mutual funds those mutual funds will supply liquidity to banks. Yet, again, 
the increased solvency risk that makes central banks reluctant to buy toxic assets will make mutual funds reluctant to recycle the liquidity they obtain.

Third, contrary to the basic assumption of cash in the market models, the supply of liquidity is not exogenously given. Yet, although, ceteris paribus, we expect the demand for securities to increase as their prices decrease, expectations and precautionary behaviour tend to reduce demand at any level of prices. Consider the case of a realization by liquidity providers that the value of the risky assets will fall. This will reduce the general demand for these risky assets, causing their price to fall. For those institutions that are funded in the wholesale market this will have a dramatic effect. On the other hand, the precautionary demand for liquid assets will increase, thus reducing the demand for risky illiquid securities as market liquidity deteriorates and risks increase. So, although potential liquidity may be plentiful, liquidity available to be invested in the market, which is effective liquidity, is in fact reduced, as the opportunity cost of a liquidity shortage increases and it becomes optimal for banks to increase the amount of their reserves. This makes more difficult the conduct of monetary policy as liquidity injection is confronted with a mechanism reminiscent of the classical Keynesian liquidity trap.

Another amplifying effect comes into play, because, as pointed out by Adrian and Shin (2007), investment banks are not passive actors but will actively manage their risk. They observe that when the price of assets increase and banks' assets grow, investment banks tend to increase their leverage. The counterpart of this behaviour is that in a downturn when banks' balance sheets shrink due to a downturn, they de-leverage by selling assets, what consequently increases the downwards pressure on the price of financial assets. The leverage ratio, which financial institutions maintain, is the ratio between the investments in risky assets which they make and the equity that they raise, and using this ratio as a target is consistent with the type of techniques that financial institutions use for their risk management. To keep a targeted level of risk, say using a Value at Risk type of risk management rule, a bank suffering a loss has to decrease its leverage, which implies, in turn, additional sales of assets and further downwards pressure on prices. Such a decrease on the price assets will reduce the value of investments of other financial institutions, and cause them to sell financial assets, which 
will lower their price, and reduce the value of the assets held by the first banks in a spiralling effect.

This effect will be particularly important for highly leveraged institutions (HLI). Such institutions invest in risky assets, which they finance by (i) raising equity and (ii) borrowing from elsewhere (i.e. by 'leveraging'). They do this leveraging either by attracting deposits, or, in the case we focus on, by obtaining funds from other financial institutions. At any point in time, the value of the equity of these institutions depends on the value of the investments in risky assets which they hold minus the value of their borrowing. Their leverage ratio then equals the value of these investments relative to the value of their equity, where the value of that equity is computed in the way just described.

The initial price decrease in asset prices will be magnified through a multiplier effect, coming from the HLIs. This multiplier effect works as follows. Falling asset prices force down the value of the HLI's investments. But since the value of their equity is a residual after subtracting their own borrowing from the value of these investments, their leverage ratio will rise after the asset prices fall, since the proportional fall in the value of their equity is more than proportional to the fall in the value of financial institutions which they hold. This means that they will need to contract their balance sheets, by selling some of their investments and so reducing their borrowing. They do this in order to enable their holdings of investments to fall in with the value of their equity. But such sales of risky assets will lead to further reductions in the demand for these risky assets. That will lead to further falls in the price of these assets. That will cause further contraction in the value of HLI's balance sheets, further sales of assets by HLIs, further falls in asset prices, etc, etc.

It is worth noticing that the decrease in balance sheet of banks implies may imply a lower demand for liquidity as the need to finance long term investments is reduced with the sale of the asset. Of course, this depends on the structure of long term vs. short term funding of financial institutions, but the sale of assets also contains an offsetting, stabilising, effect, operating through its effect in reducing the demand for financing by HLIs. 
Finally, the use of mark-to-market accounting rules implies that a decrease in the price of an asset immediately leads all banks to acknowledge losses. Even those banks that were not affected by liquidity shock will then, in turn, be forced to sell some risky assets in order to reduce their capital requirements.

The second mechanism that leads to contagion through liquidity is the margin/haircut spiral mechanism (Brunnermeier and Pedersen, 2009) that develops in the repo market. ${ }^{4}$ As emphasized by Brunnermeier and Pedersen, there is a link between liquidity in the repo market and the ability of financial institutions to obtain funds (funding liquidity). This makes a liquidity shortage propagate from the market to the balance sheet of financial institutions. To see how the haircut spiral operates, consider the case of a bank that wants to finance ten year bonds by issuing a revolving one month repo, corresponding from an economic point of view ${ }^{5}$, to a one month loan using the bond as collateral. If the portfolio of bonds is initially valued 100 and its haircut is 5 , then the bank can raise 95 through a repo operation and has to bring in only 5 as equity. If the bond is suddenly considered more risky by investors and the haircut increases, say to 10 , the bank will have to raise 5 in additional equity. If this is not possible, as it happens during a financial crisis, the bank will have to sell part of the portfolio. By selling 50 it will then be able to repo the other 50 and balance its liquidity needs. The same effect will occur if the market price of the asset diminishes. Therefore, for those institutions that are funded with repo operations, an increase in haircuts and a decrease in prices will increasing the pressure on the price of financial assets and generate, again, an amplifying mechanism: price decreases trigger the sale of the assets that lead to price decreases.

Notice that, contrarily to the classical macroeconomic assumption about the demand for money, here interest rates play no role: the liquidity need is independent of interest rate.

\footnotetext{
${ }^{4}$ A repo or repurchase agreement is an operation whereby a security is sold with the commitment by the seller (dealer) to buy the security back from the purchaser (customer) at a specified price at a designated future date. It is equivalent to a collateralized short-term loan where the collateral is the security, but has a better legal protection. The haircut is the difference between the actual market value of a security and the value assessed by the lending side of a transaction, the latter taking into account a possible decrease in the value of the asset at the time of the security buy back as well as a risk premium. A haircut protects the lending side against the risk of a decrease in the value of the security that it buys under the repurchase agreement.
} 
How important the haircut spiral will be depends upon two features related to financial structure: what banks resort to repo operations in wholesale markets and what type of securities the banks hold. Both phenomena have combined in the recent crisis to make the haircut spiral particularly powerful.

First, regarding banking structures, there has been a revolution in banking business models. with a switch from the classical lending model of originate-to-hold where the loan was kept in the banks' asset and finance by the banks' liability to the originate-todistribute business model, where loans are sold to a special purpose vehicle that, itself, will sell shares and bonds. This transformation has played a key role in the development of the current crisis, as it has led to special purpose vehicles that were not regulated by the banking authorities to issue short-term debt backed by the originating banks lines of credit. Obviously this created a risk for the originating bank, but under Basle II rules this risk did not require as high a capital requirement as under the originate-to-hold business model, thus allowing for regulatory arbitrage. Consequently, as banks switched from one business model to the other they progressively economized on capital while taking more liquidity risk adapted their business model to benefit from the easy access to wholesale liquidity that well-functioning financial markets provided. In recent years this has led banks as well as "shadow banks" to increase their maturity transformation function by creating special purpose vehicles that held securitized loans (long maturity) while financing them by means of short term repos. These strategies benefited the originator, of course, because of the existence of a spread between the long run and the short run rate, but at the cost of an increased liquidity risk that was often underestimated. It also implied a higher impact of haircut spirals.

Second, the haircut spiral will be more or less noteworthy depending upon the type of assets banks hold. If these are government bills, haircuts will be negligible. Instead, if risks affecting cash flows are sufficiently high or characterized by asymmetric information as it happened with the CDOs in the current crisis, (See Gorton and Holmstrom, 2008) the haircut spiral will be a key amplifying mechanism, because an increase in the risk and asymmetric information of an asset will shorten its liquidity. With the popularity of securitization, these securities where often related to subprime mortgages and, in any case subject to risk and asymmetric information. As mentioned by Cassola et al (2008), "The main reason why general uncertainty increased so 
dramatically in the summer of 2007 is the fact that the market realised, first by means of losses in sub-prime securitisations, that the current practices used for valuations primarily the valuation of structured finance - were unreliable. Often this pricing was based on ratings and the transaction prices of supposedly similar instruments. The risk assessments of rating agencies turned out, however, to be flawed. Moreover, contrary to accounting assumptions, for most of these instruments liquid markets with observable prices never really existed". This is how haircut spirals developed with an extremely negative impact on prices.

As described, liquidity contagion explains how a liquidity shock in one bank may be transmitted to the whole banking industry, mainly because of the impact liquidity shocks have on the price of financial assets, a contagion mechanism that contrasts with the classical ones, whether based on direct contagion or on bank runs. Still, in addition to these indirect effects through prices, the direct contagion effects that come from reciprocal obligations between bank and non-bank financial intermediaries must be acknowledged.

This has led to concern among regulator that has witnessed how the extent of the banking risk was beyond the areas of their responsibility.

Indeed, the present crisis has shown that in a well developed financial market the distinction between banking and financial markets is fictitious. By making use of financial innovations, certain non-bank financial institutions carry out of a number of functions traditionally attributed to banks. This has generated a network of reciprocal obligations between banks and certain non-bank financial institutions that gave them a systemic character. The contagion effects of Lehman bankruptcy ${ }^{6}$ or the potential contagion effect induced by AIG had originated precisely in the systemic character of these institutions, which were taking huge banking risk without being submitted to the tighter regulation of commercial banks.

\footnotetext{
${ }^{6}$ The spectacular impact of the Lehman bros. default on September $16^{\text {th }}$ on the money market mutual funds shows that the contagion can go even further. The run on money market funds was stopped by the Treasury guarantees, but such a run, had it continued, would have impacted not only on the price of liquid assets but also on the liquidity of financial institutions that were financed by the issue of short term debt and certificates of deposits bought by those funds.
} 
The different contagion and amplifying mechanisms we have described will obviously combine in generating fire sales and asset prices decreases. One may wonder whether this will spiral out of control, or will be contained. Indeed, if all financial institutions are HLI that behave as predicted by Adrian and Shin and Brunnermeier and Pedersen the process is unstable and leads to a zero price for financial assets, the financial institutions assets reach zero so that they all become bankrupt. This will also be the case if the dynamics of expectations formations leads to additional fire sales. Still, this seems as an extreme, unrealistic, case, as the value of cash balances in terms of financial assets would be infinite. Still, if we define as "unstable" any process that leads to a generalized banking crisis (defined by the insolvency of the major financial institutions), and then a sufficiently low asset price will generate financial instability. The crucial issue is then whether the equilibrium price that assets will obtain in the absence of central banks support is sufficiently high for the main financial institutions to remain solvent. If the drop in financial asset prices leads to a generalized banking crisis, then the central bank intervention may be welfare improving, as shown by Gertler and Karadi (2009) in a DSGE framework capturing some of the features of the current crisis.

\subsection{The subprime crisis as a trigger}

The role of the third component of a classical systemic crisis, namely the trigger, has in this case been played by the subprime crisis. As delinquencies increase in the subprime mortgage market, holders of risky assets came to realize that the value of these assets would fall. This reduced the general demand for these risky assets, causing their price, as well as the price of structured products that included them (ABS, CDOs...) to fall. It was this initial effect on the price which was magnified through a multiplier effect, of the kind discussed above.

The subprime crisis has been the result of an aggressive high risk lending policy combined with the extensive use of the "originate and distribute" model. The competitive pressure on the margins of traditional mortgages, led to the search of new, less competitive credit markets. Subprime lending was based on credit to borrowers that did not meet the usual credit standards and therefore for which competition was not so harsh. The expected profitability of lending to these marginal borrowers was based on expected further increases in the price of real estate combined with a stable proportion 
of non-performing loans. The loans were structured in such a way that they required small instalments during the first two years followed by a longer term variable rate loan with a high margin.

The changing macroeconomic conditions combined with the decrease in house prices and increased interest rates led to a sharp increase in delinquency on subprime loans during 2006 and 2007, particularly for those originated in 2005. Such a change in the risk assessment of these assets was a trigger because directly or indirectly through CDOs and other securities using the yield of mortgages as the underlying for its cash flows were held by commercial banks. The impossibility to know the impact of subprime loans on each bank solvency led to a freeze on liquidity, particularly in the unsecured interbank market, because of the difficulty to assess counterparty risk.

\section{Unconventional Monetary Policy Operations}

We will now turn to examine how central banks have reacted to the recent turmoil with unconventional interventions. We will argue that these are unconventional on three grounds:

1. The substantial amount of liquidity injections.

2. The interest rate decrease.

3. New channels for liquidity injection created or adapted with central banks accepting risky assets as collateral.

These measures can be understood in light of the amplifying mechanisms of the crisis as analysed in the previous section: injecting liquidity at low interest rates decreases the selling pressure on financial assets for both the cash in the market and haircut spirals mechanisms. Yet, for liquidity to be injected it is necessary to accept as collateral the assets available in banks' balance sheets, which imply that central banks had been forced to lend not only against safe assets, but also against risky collateral. Finally, the collapse of the interbank market implied that the channelling of funds from one market to another could be severed with situations where, for instance, primary dealers could be liquidity trapped while other major banks had the required liquidity but could not lend it because of the temporary absence of an efficient interbank market. Consequently, central banks had to find new refinancing channels for those assets that could not be financed in other ways and thus threatened the solvency of some financial institutions. 


\subsection{Liquidity injection}

The magnitude of this liquidity injection that has taken place can be measured by the spectacular increase of central banks' balance sheets after the Lehman brother's crisis, with the Federal Reserve and the Bank of England balance sheet doubling in size in a few weeks while the ECB and the Swiss National Bank ones were boosted by $30 \%$. (See diagram 1)This impressive expansion reflected different combination of growth in central banks' liabilities. There was often a rise in bank reserve balances with the central bank, but several central banks took steps to manage their liabilities more flexibly. Also, several central banks started to issue their own bills (Bank of England, Riksbank and Swiss National Banks) and the Federal Reserve started to remunerate banks reserves. The corresponding increases in the assets held by central banks were different from one central bank to another as their policies were markedly different, as we will see hereafter.

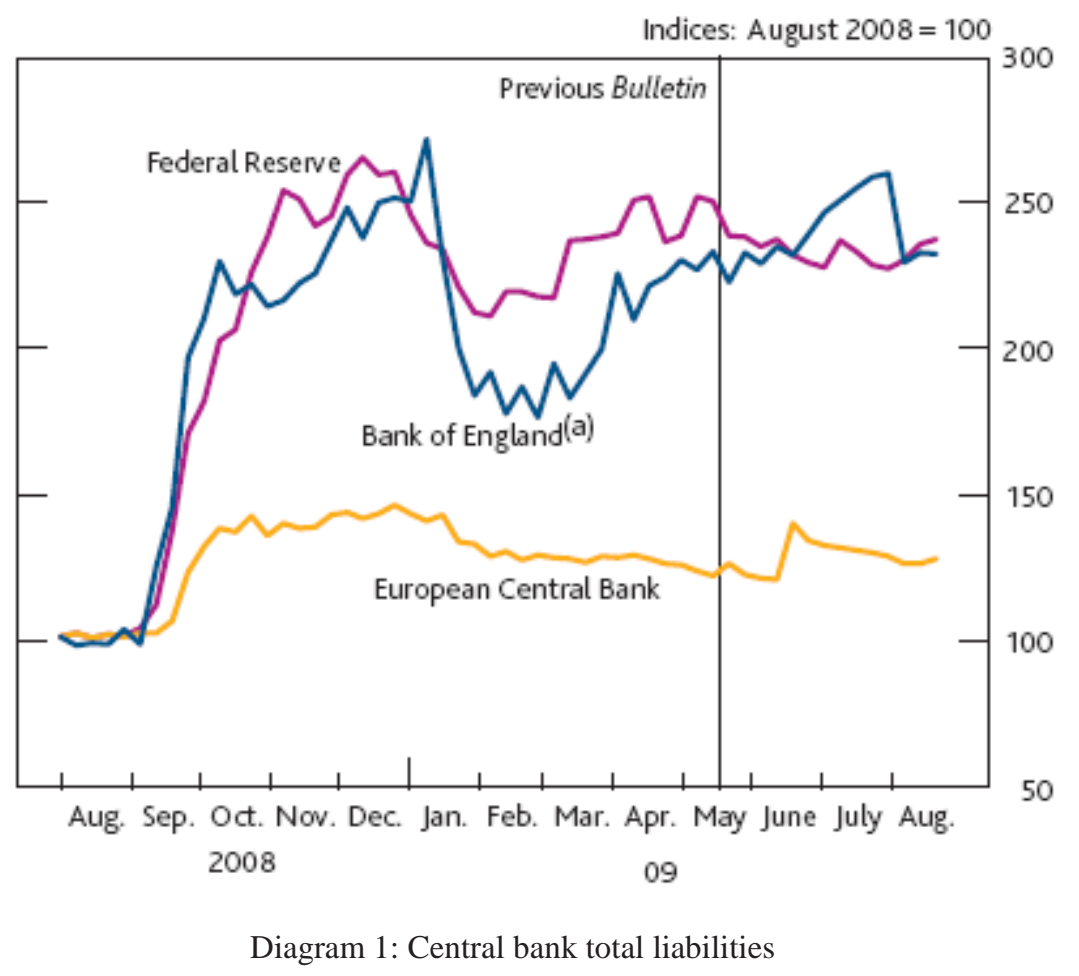

Source: Bank of England Quarterly Bulletin 2009 Q3 
At the international level, the cooperation among central banks has been particularly strong, as witnessed by the simultaneously cut in their interest rates by six major central banks on October $8^{\text {th }} 2008$. Also, it has allowed coping with the sudden large demand for dollars through the expansion of the US Federal Reserve's currency swap lines, as on October $13^{\text {th }} 2008$, major central banks jointly announced measures to improve liquidity in short-term US dollar by agreeing to a $\$ 180$ billion program of US dollar swap lines between the Federal Reserve and the other central banks. In a joint statement, the central banks said, "These measures, (...) are designed to improve the liquidity conditions in global financial markets. The central banks continue to work together closely and will take appropriate steps to address the ongoing pressures."

Both the increase in money injection and the unparalleled levels of cooperation contrast with the nationalistic centrifugal forces in the crisis of 1929. While, according to Friedman and Schwartz (1963) the money supply decreased by one third between 1929 and 1933, the Fed policy has consisted in aggressively increasing the monetary base, while closely following the evolution of monetary aggregates M2 and M3 so as to prevent major tensions. The international cooperation has limited the fluctuation of some of the currencies in major developed countries ${ }^{7}$.

\subsection{Interest rate setting}

The following diagram shows the main changes on the interest rate that are used as a reference for the conduct of monetary policy.

\footnotetext{
${ }^{7}$ But notice the spectacular depreciation of the sterling pound and the appreciation of the Japanese Yen.
} 


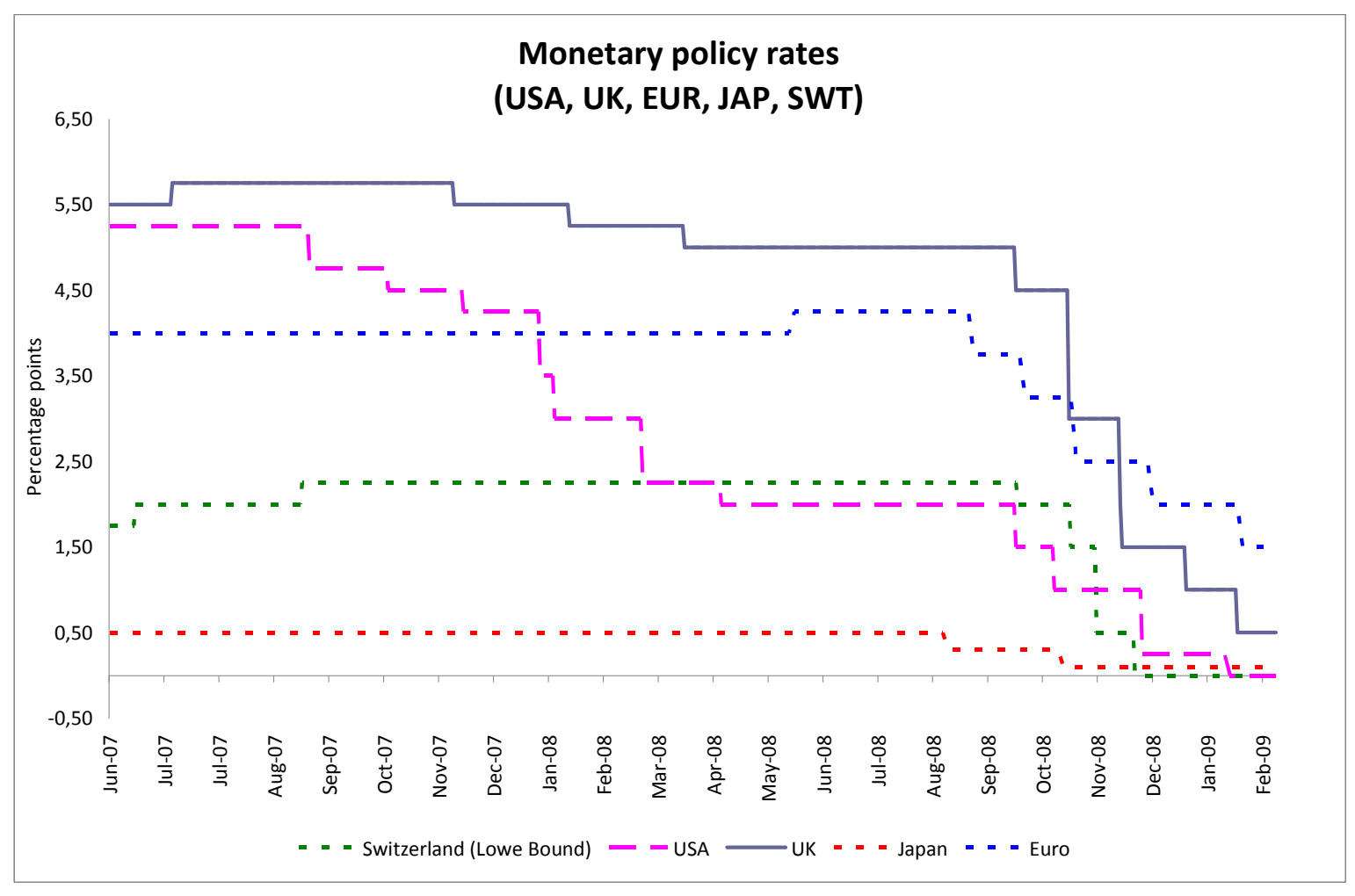

Diagram 2

The magnitude of the interest rate cuts as well as the frequency of interventions is unprecedented.

The decrease in target interest rate central banks has been a key instrument to limit contagion. As usual, a decrease in interest rate is the central banks normal response to a business cycle contraction. In so far as the crisis was indicative of a downturn, it was therefore a natural move that allowed reducing the impact of the downturn. Yet, the decrease in interest rates was here intended to go beyond this classical effect. First, by signalling a policy of low interest rates, the central banks intervention made profitable both existing and new investment projects by revaluing their net present value. This implies that all things equal the price of financial assets increase, thus creating an opposing force to the impact of liquidity shortage on the price of assets. Consequently, an interest rate decrease helps to dampen down the contagion effects of liquidity shortages. Second, lower interest rates limit the cost for banks to obtain the required liquidity from the central bank, so that this does not add to their losses.

Following this policy, the commitment to low interest rate was clearly announced by the Federal Reserve on its press release when it stated "that weak economic condition is 
likely to warrant exceptionally low levels of federal funds rates for some time" (Minutes of the FOMC, December $15^{\text {th }} 16^{\text {th }} 2008$ ).

Central banks also managed the whole array of interest rate by managing the interest rates commercial banks obtained on their liquid reserves. In the US, the Fed began to pay interest on bank reserves; in Europe, the Bank of England and the ECB narrowed the corridor between the rates of lending and deposit facilities, while in the US the Fed reduced the spread between the discount window rate and the fed funds rate.

\subsection{New channels for liquidity injection}

Traditional monetary policy operates through a unique target rate, mainly the repo rate, whose changes are expected to be transmitted to the whole economy through the financial system. In this way, by using a unique port of entry central banks can affect the whole range of interest rates, as the risk return trade-offs will transmit the interest rate changes to other financial markets. In particular, the intertemporal structure of interest rates, jointly with the expectations created by monetary policy, will transmit part of the interest rate changes to the market for longer term debt, and likewise the risk structure of interest rates will do so for risky debt. When confronted with the current crisis, liquidity injection through a unique port of entry may fail to provide liquidity to the right institutions. This is the case because the crisis is characterized by the freeze of the interbank market that constitutes the hub of liquidity redistribution. This explains that in the recent central banks' interventions, we have witnessed, in addition to changes in the target interest rate, an impressive number of newly created facilities, so as to transmit interest rate changes or to directly affect the different segments of the market for liquidity.

The Federal Reserve has been particularly active in the design of new facilities to provide funds to banks and security dealers through the newly created lending facilities. Following Bernanke (2009), it is possible to identify three types of instruments:

- The first set of tools relates to the central bank's role as the lender of last resort and emergency liquidity assistance. It consists of the Term Auction Facility 
(TAF) Term Securities Lending Facility (TSLF), the Primary Dealer Credit Facility (PDCF) and swap lines.

The TAF offers term funding to depository institutions via a bi-weekly competitive auction. The TSLF is a term lending facility for primary dealers established on March $11^{\text {th }} 2008$ that allows primary dealers to obtain a loan of Treasury securities using as collateral relatively illiquid program-eligible securities. Finally, the PDCF, announced to the board on March $16^{\text {th }} 2008$ allows primary dealers to borrow overnight from the Treasury against a broad range of collateral.

- The second set of policy tools is intended to provide liquidity directly to borrowers and investors in key credit markets. It consists of the Term AssetBacked Securities Loan Facility (TALF) Commercial Paper Funding Facility (CPFF), Asset Backed Commercial Paper Money Market Mutual Fund Liquidity Facility (AMLF) and the Money Market Investment Fund Facility (MMIFF) The TALF, announced by the Federal Reserve on November $25^{\text {th }} 2008$ is a $\$ 200$ billion facility, to extend loans against securitizations backed by consumer and small business loans. Also, the support to the mortgage market was implemented by means of the specialized agencies, purchases of bonds and mortgage-backed securities issued by Fannie Mae, Freddie Mac and the Federal Home Loan Banks, while the purchasing of commercial paper took place through the Commercial Paper Funding Facility (CPFF), announced on October $7^{\text {th }} 2008$. The Fed also created two facilities to lend to Money market funds (AMLF, announced on September 19th 2008 and MMIFF, announced on October $21^{\text {th }}$ 2008) thus helping money market mutual funds to cope with the continuing flow of redemptions.

- The third set of policy tools is aimed to support the functioning of credit markets involves the purchase of longer-term securities for the Fed's portfolio.

In a similar vein, in its effort to improve commercial banks access to liquidity, the ECB switched the existing framework for monetary operations in two ways: in mid-October 2008 the ECB introduced fixed rate tenders with full allotment. This resulted in an increase in the availability of bank funding. Banks securitize their portfolio of loans 
with the unique objective of using it as collateral in order to obtain ECB funding. Secondly, the ECB increased the maturity of repo operations while accepting a broader range of collateral. The percentage of Government securities dropped to an unprecedented level of $44 \%$ of the nominal value of securities on the list. The mechanism was already in place before the crisis and the ECB simply accepted a wider range of private paper (Trichet 2009). The combination of these different mechanisms implies that, de facto, banks have been granted access to unlimited liquidity at the ECB policy interest rate at maturities of up to six months extended to 12 months in July 2009 (Governing Council decision of May $7^{\text {th }}$ 2009).

\subsection{Real Sector Interpretation}

Could the unconventional monetary policy interventions be justified by concerns regarding the real sector, and, specifically the possibility of a recession? We argue that such a justification is implausible. Two arguments can be constructed. First the concern about both a recession and deflation will trigger a liquidity injection and a decrease in interest rates under standard monetary policy rules. Second, concern about recession may have led central banks to promote monetary policy interventions so as to foster credit to the real sector. We consider these two arguments hereafter.

First, the conduct of monetary policy during the systemic crisis cannot be put on the Procrustean bed of inflation targeting implemented in "normal" times. It has been clear from the crisis start that there was a major concern about the real recession and the possible deflation. Yet, the aggressive monetary interventions have taken place before any information concerning a possible recession was clearly established. Of course it could be argued that the impact of the credit recession could have helped monetary authorities forecasting significant joint movements of recession and deflation. But the idea of conducting inflation targeting without any reference to the changes in the actual business cycle indicators seems quite farfetched. In fact, the objective of monetary policy injections was to limit the impact of financial contagion and to prevent the complete collapse of financial markets. Of course, by so doing, a positive impact on the extent of recession and deflation is obtained. In addition, supporting our view of a qualitative change in monetary policy is the fact that, as we have shown in the previous section, central banks have been injecting liquidity not just through the usual channels, 
but also through new lending mechanisms that provided the institutions with funding for a longer maturity and against a broader type of collateral.

Consequently, in our search for a consistent framework for the analysis of monetary policy interventions during the systemic crisis, we will discard the standard models of monetary policy aimed at generating stable sustainable long run growth without inflation that would have implied a more gradual and moderate approach.

Second, an alternative explanation for the recent central banks' interventions would be to consider Trichet's (2009) statement asserting that "Our primary concern was to maintain the availability of credit for households and companies at accessible rates. ». Clearly, the environment of monetary policy has changed, as the transmission mechanisms, either through the participation of primary dealers, as in the US, or through the interbank market as in the EU have changed. It would therefore be consistent with a "credit view" of monetary policy to follow closely the aggregate amount of credit to the economy as the main driving force for central bank liquidity injections decisions. The drawback of this view is that it takes for granted that the interest rate cuts and the liquidity injections enforced by the monetary authorities are passed through to the final borrowers. It is dubious that banks increased on their supply of credit for three reasons:

First, the spreads and conditions on loans depend upon the business cycle, with banks increasing their margins and their credit standards at the beginning of a downturn. Second, liquidity shortages may lead banks to invest in more liquid assets that constitute a liquidity buffer. Third, commercial banks' losses have eroded their capital, so that in order to satisfy capital requirements they may prefer to invest in low risk assets, such as treasury bills, as witnessed in the US credit crunch after the Saving and Loans crisis or in the South East Asian crisis in the aftermath 1997 crisis. In spite of these three reasons, a decrease in loan interest rates may occur in loan contracts at variable rate. The problem is, nevertheless that it does not affect new loans, but existing ones, and in some countries, like the US or France where interest rates are fixed or in countries like the UK where interest rates are renegotiated, the decrease in interest rates will combine with an increase in bank margins. Consequently, it seems difficult to accept Trichet's point of view and consider the supply and cost of credit to borrowers as the benchmark against which we will measure the success of central banks' interventions. Still, it may 
be argued that the final test is in the data: to what extent final borrowers' interest rate have decreased?

To answer the issue of credit availability it is obvious that the demand conditions are such that we are entitled to expect a decrease in the supply of credit. We do observe negative rates of growth for both consumer and corporate loans.

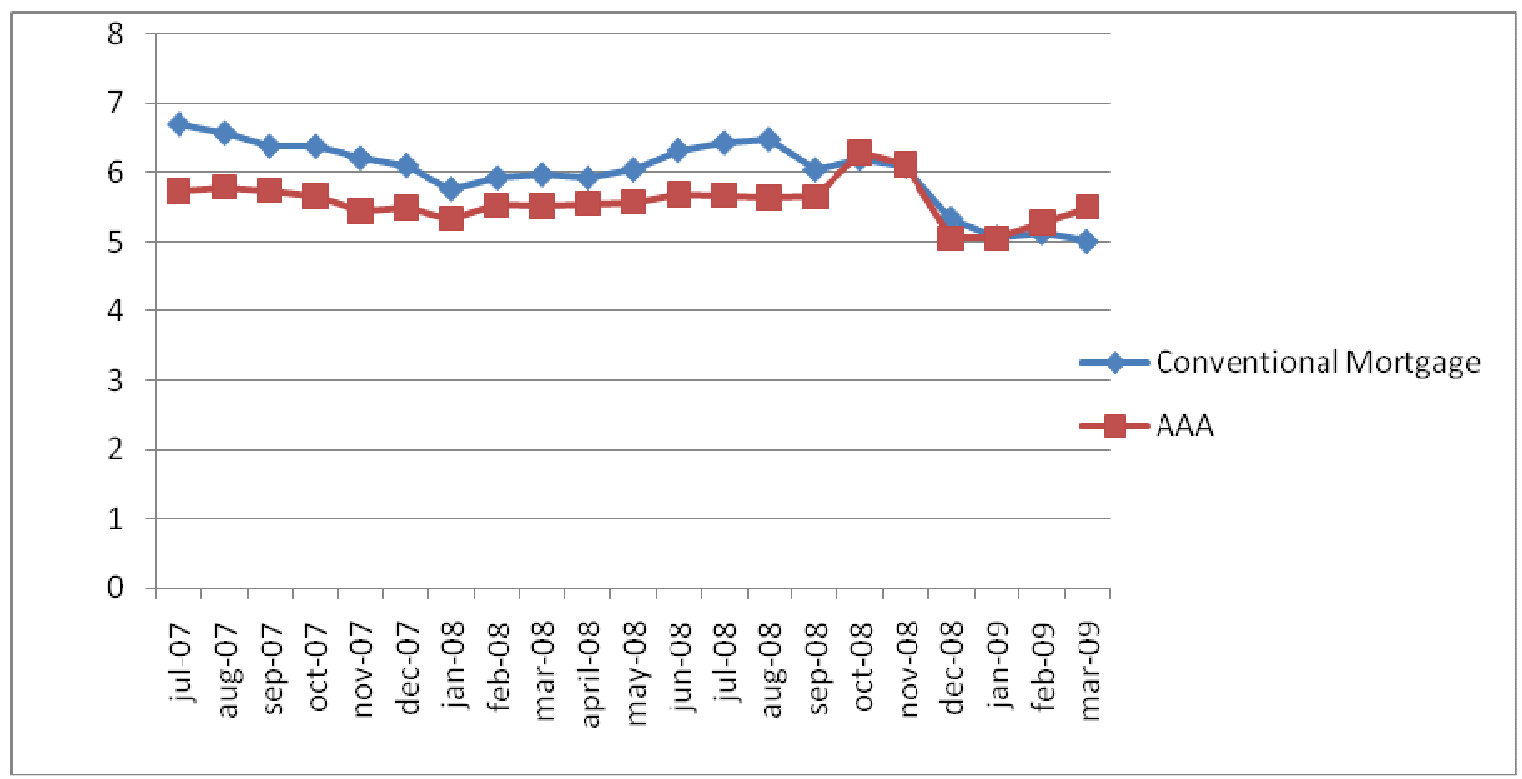

\section{Diagram 3}

US Monthly rates, 07/2008 to 03/2009

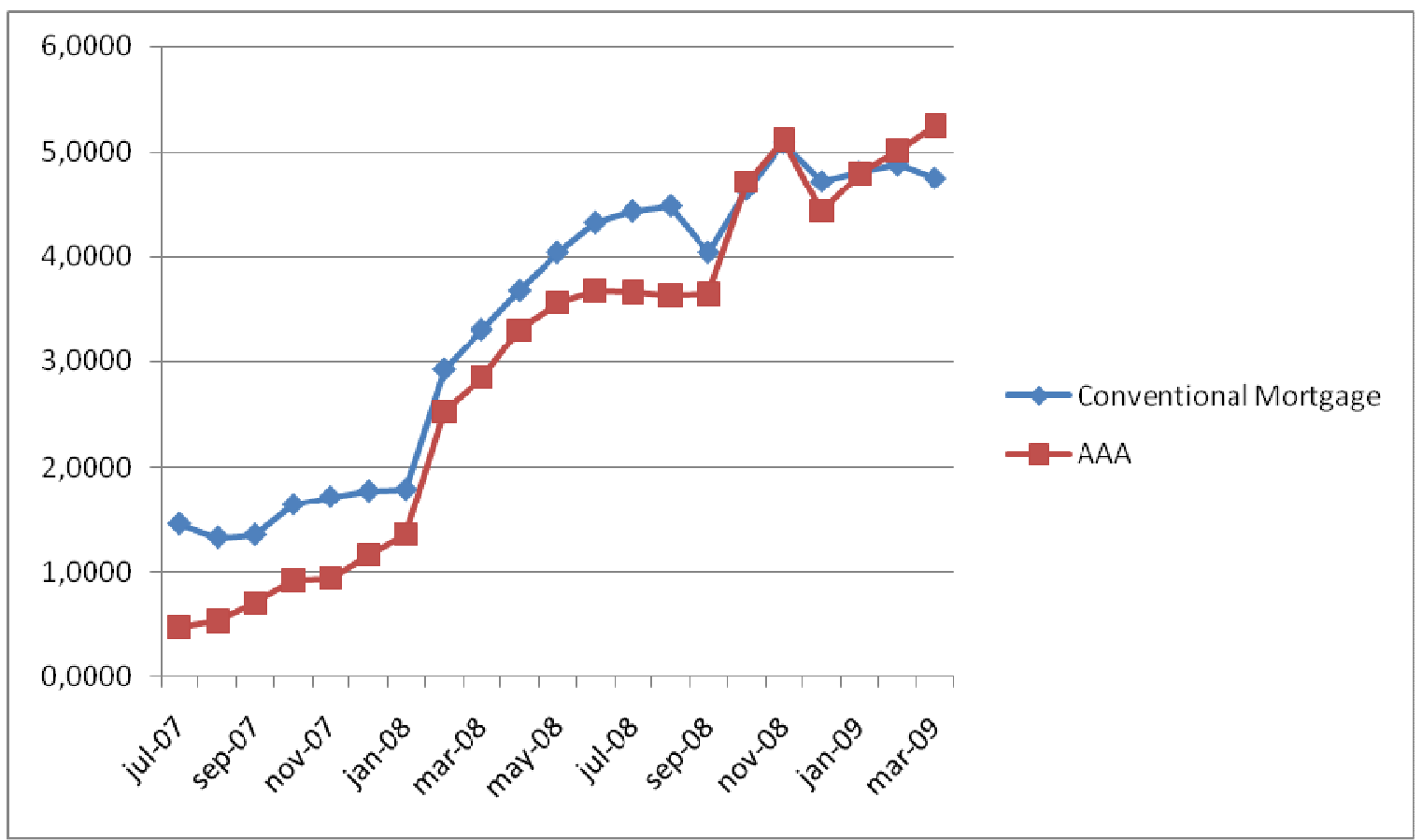

\section{Diagram 4}

US Monthly Spreads, 07/2008 to 03/2009 
Regarding interest rates, as illustrated in diagrams 3 and 4 the data shows that the aggressive cutting of target interest rates does not seem to have had a significant impact on retail interest rate. Clearly the interest rates decrease has been compensated by an increase in the spreads. Of course, it may be argued that the effect has not been seen yet, as monetary policy operates with a lag and that absent the expansive monetary policy, the increase in borrowers' interest rates would have had much more pronounced. Still, in the absence of additional information, we are bound to think that monetary policy has not played a key role in improving the final borrowers' credit conditions.

Consequently we will consider that the objective of central banks intervention has been to preserve the well functioning of the banking system, by operating as lenders of last resort, which does not fully contradict Trichet's view, as it appears as a necessary condition for banks lending, even if the credit supply has decreased.

To summarize, the policy that central banks have followed has consisted in injecting liquidity at low interest rates, bypassing the collapsed interbank market and creating new refinancing facilities. By so doing central banks were able to limit the crisis liquidity contagion mechanism. We will now show that the theory of the lender of last resort provides a sound foundation for the central banks behaviour during the crisis.

\section{Monetary policy during a crisis, lessons from the theory of lender of last resort}

The previous two sections considered the complexities of the contagion mechanisms in the current crisis and how central bank reacted by implementing a number of measures to inject liquidity and to limit the worst effects of the contagion mechanisms. In order to assess the logic of central banks' interventions since the beginning of the crisis we will now turn to examine alternative lender of last resort models that could justify it. This will therefore be quite a partial and unfair review of the literature on the lender of last 
resort that is only justified by the precise objective here pursued, which is to identify the role of the lender of last resort in a systemic crisis with the specific liquidity shortages characteristic of the current one. We will argue that a forceful lender of last resort policy following the lines of the one we have witnessed is fully justified on the basis of the conclusion of some recent theoretical lender of last resort.

We will begin by examining as a benchmark the classical view of the lender of last resort in an environment of perfect information and then turn to the more complex issue of its implementation.

\subsection{The classical theory of the lender of last resort}

The existence of a lender of last resort is directly linked to the functions of banks in the economy. If we agree that one of the major roles of banks is to transform long term illiquid assets (loans) into short term demand deposits that can be used as means of payment, then we have to acknowledge a fundamental fragility of banks: the mismatch between its long term assets and its short term liabilities. In normal times, the law of large numbers implies that a bank's independently distributed random liquidity shocks partially cancel out, resulting in an aggregate liquidity shock the bank can easily manage. Still, when a sufficient number of agents run the bank on the basis of rumours, this may provoke the bankruptcy of an otherwise sound bank. The mechanism in place to provide liquidity to sound banks facing such a bank run is the lender of last resort facility that will prevent the banks' liquidation for pure liquidity reasons.

As a starting point it is useful to refer to the classical theory of the lender of last resort, as developed by Bagehot. Indeed, although the banking and financial industry has drastically changed -in particular with the introduction of fiat money, the payments technology and derivatives - Bagehot's basic recommendation is still up to date as it helps positing the role of the lender of last resort. Bagehot stated that the lender of last resort should provide liquidity, but only to illiquid solvent institutions at a penalty rate and against good collateral.

The simplest representation of bank runs is the one provided by Diamond and Dybvig in a model where agents may coordinate on two different equilibria: either all agents run the bank by withdrawing its deposits or they wait, and only the second equilibrium is efficient. The paradox is that if a sufficient number of depositors decide to run the bank, 
then it is optimal for all depositors to run the bank. This is so because the banks' commitments to pay depositors that withdraw may leave the bank with insufficient resources to credibly fulfil its contractual obligations to those depositors that are not running the bank. In such a context the Bagehot policy is well defined, as the model assumes the bank's assets are safe, and therefore all banks are solvent and assets are "good collateral". The lender of last resort policy implies lending generously to any bank at the riskless interest rate against its illiquid portfolio of long term investment. This comes at no cost because it simply allows agents to coordinate on the efficient equilibrium. As a consequence, in such a simplified world the diagnostic of the crisis is that a panic situation has developed and the treatment is for the central bank to lend as much as required to all banks against the illiquid collateral. Still, when we depart from the ideal model, and bring in risky collateral such as "toxic assets" the application of the classic doctrine is no longer straightforward.

\subsection{Implementing the lender of last resort policy}

In the context of today's financial markets the interpretation of the classical rules leaves much open to interpretation.

\subsubsection{A Macroeconomic lender of last resort}

To begin with, in a well developed financial system, the existence of a repo market allows access to credit for any institution independently of its own creditworthiness. So, if we interpret "good collateral" as collateral used in the market for repos, we have a first interpretation of the lender of last resort. This was first put forward by Goodfriend and King (1988), who argue that the existence of a fully collateralized repo market allows central banks to operate only through the repo market, supplying the required aggregate amount of liquidity which is then allocated by the interbank market. This view has the advantage of leaving the distinction between illiquid and insolvent banking institutions to market participants, so that regulatory authorities do not have to assess the solvency of banking institutions in need of funds.

By injecting liquidity in this way, banks are confronted with market discipline, because any doubt on their solvency will deprive them from liquidity and condemn them to bankruptcy. This eliminates lame ducks (as in Chari Jagganathan, 1988) and limits 
moral hazard (as in Calomiris and Kahn, 1991). Thus, theoretically, a perfect interbank market would result in an efficient banking industry.

Unfortunately, there are three weaknesses with the assumptions implicit in this argument that becomes particularly disturbing in the context of a systemic crisis.

- First, if a generalized panic develops the amount of T-Bills the banks can repo is insufficient to stop the bank run. In this context, banks that are liquidity-long will refuse to lend to liquidity-short banks because if the run continues the borrowing bank will go bankrupt.

- Second, market discipline during a systemic crisis should be reconsidered because of the existence of contagion externalities. In particular, as mentioned in relation to the current crisis, asset liquidation has an impact on the asset prices and on asset haircuts which, in turn, lead to banks' insolvency. This is directly related to our previous point, the existence of a panic, as during a panic market discipline simply vanishes. Thus, the social cost of liquidating an institution during a systemic crisis should take into account the fact that banks are too interconnected to fail.

- Third, the interbank market that plays a key role in channelling liquidity from liquid institutions -with access to the central bank liquidity- to the illiquid solvent ones may simply collapse. The reason for this is the existence of asymmetric information that may lead to higher spreads and, in the end to the complete disintegration of the interbank market (A point developed in Freixas and Holthausen, 2005 and, more recently in Heider, Hoerova and Holthausen, 2009). In this case liquid efficient banks may go bankrupt because they are throttled in spite of other banks being flooded with liquidity.

Consequently, injecting liquidity against T-bills at the aggregate level would have been unsuccessful to cope with the extent of the systemic crisis that combined a liquidity run, inefficient market discipline and the collapse of the interbank market. This is unfortunate, as intervening at the aggregate level through safe repo operations allows the lender of last resort to operate without risk. Once we acknowledge that there are not enough safe assets to guarantee the solvency of those banks in need of liquidity we are forced to abandon the "T-Bills only" option for the lender of last resort intervention. In other words, strictly abiding by the classical principle of lending to illiquid solvent banks will be insufficient to solve the crisis. 
The implication of this inability to intervene at the macro level through riskless loans is that the only feasible intervention has to be through risky operations. This means that

1. The accommodation of the classical lender of last resort policy to a systemic liquidity crisis context implies lending against risky assets at the aggregate level.

2. By so doing, the lender of last resort policy disregards the solvency of the borrowing institution. With some probability this will result in liquidity being provided to inefficient banks, the very same lame ducks that we would like to eradicate in the long run.

3. The concept of "good collateral" has to be defined in a realistic way, providing liquidity without providing a generalized bail-out for the whole banking industry.

4. In order to fine tune the lender of last resort loans, the regulator has to consider the cost-benefit analysis of risky lending that will result in the designation of the collateral eligible during the crisis.

5. As a consequence the ideal "emergency liquidity assistance" cannot be distinguished from bank bail-outs.

6. So, the macroeconomic lender of last resort policy once adjusted so as to provide a sufficient amount of liquidity has to be asset based. By contrast, the microeconomic perspective will be institution based.

\subsubsection{Microeconomic lending of last resort}

In addition to allowing for the forbearance of insolvent institutions, the macroeconomic approach may rely excessively on the perfect interbank market assumption. As a consequence, it underestimates the possible network effects of lending among banking institutions that may be characterized by the heterogeneity of institutions, (large vs. small, retail vs. wholesale, money centre bank,...) as well as the lending relationships that emerge from repeated interactions that provides access to better information on the counterparty. This network effects may be crucial in the contagion effects that characterize a systemic crisis.

Network effects are considered in Allen and Gale (2000) model where it is efficient for banks to sign ex ante agreements to insure against individual liquidity risks, but this network of contracts may then lead to a domino effect in case of aggregate risk. 
A slightly different framework is explored in Freixas et al. (2000), who establish the existence of two equilibria, one of which is an inefficient "gridlock equilibrium", where the interbank market freezes. While in the former set up liquidity injection through open market operation would restore the efficient allocation, in the latter it would be inefficient. Indeed, as the interbank market connection collapses, the efficient intervention is to lend to specific institutions. Namely, the lender of last resort policy (which is also a bail-out policy) implies when solvency is observable:

1. Lend to all institutions that are solvent

2. Liquidate all insolvent institutions but lend to all solvent institutions that are connected to the insolvent one.

Unfortunately, in a more realistic framework, where banks' solvency cannot be observed, the decision would be similar and should be taken on the basis of the expected costs and benefits. The key point is here that, in contrast with the macroeconomic view that implies lending against risky assets, the objective here is to lend to specific institutions and, in case of liquidation of an institution to provide liquidity to those most directly affected in the network.

\subsubsection{Introducing asset sales}

A natural extension of these models is to consider liquidity triggered fire sales and their effect on asset prices, as these play a key role in the contagion process. The issue is here to determine the optimal lender of last resort policy regarding asset purchases, direct loans and bail-outs, thus taking into account the impact of liquidity on asset prices and, consequently, on banks' solvency.

Rochet and Vives (2004) model the interbank market and show that because of a coordination issue, the market will lead to the inefficient closure of a fraction of solvent banks. The implication is that capital requirement regulation must be complemented with lender of last resort interventions

An alternative view of the joint liquidity/insolvency crisis is developed by Acharya and Yorulmazer (2006), using a cash-in-the-market type of approach (as developed by Allen and Gale, 1994, 1998) where the liquidity available depends upon the profits made by surviving banks. Since bank failures imply the liquidation of the assets, the higher the number of bank failures, the lower the asset prices. So, bank failures constitute a 
cumulative phenomenon: they depress the price of banks' assets and this, in turn, increases the number of bank failures. Optimal lender of last resort interventions have, therefore, to take this effect into consideration. Their result is the following: when the number of bank failures is low, it is optimal to exert market discipline and the lender of last resort should not intervene, but when this number is sufficiently large, the regulator should optimally adopt a mixed strategy, and choose to assist a fraction of the banks. By so doing, the regulator limits the negative impact banks' bankruptcies have on liquidity and on the asset prices, while she does not commit to provide liquidity assistance to all banks as this would be excessively expensive. So, as it is quite intuitive, the introduction of asset prices leads to recommend the purchase of assets by the lender of last resort. When the liquidity shortage is significant, central banks should inject liquidity by buying assets and may have to take losses or even to bail out banks in distress.

\subsection{Interest rate setting and LOLR}

As mentioned before, lower interest rates allow limiting the drop in financial asset prices and, by so doing, slowing down the liquidity/asset prices spirals. Models of joint liquidity and solvency shocks as Freixas, Parigi and Rochet (2004) and Rochet and Vives (2004) show that the lender of last should offer loans at rates lower than the market.

For some time, it has been now clearly established that the independence of central banks is crucial to achieve a lower level of inflation. It seemed reasonable to think that this principle should extend to the possible links with prudential policy. Indeed, this is the recommendation of Goodhart and Schoenmaker (1993) that point out at the conflict of interest between a countercyclical monetary policy and a procyclicality prudential policy: as LOLR, the central bank may feel compelled to bail out banks if this is necessary to prevent a systemic crisis ${ }^{8}$. The empirical analysis of Goodhart and

\footnotetext{
${ }^{8}$ Note that separation is compatible with information sharing, as Peek, Rosengren and Tootell (1999) show that information from bank supervision helps central banks to conduct monetary policy more effectively.

Still, in spite of the recommendations regarding separation of prudential and monetary policies, the recent contribution of Ioannidou (2005) shows that, when the behaviour of the three primary US federal regulators - the Federal Deposit Insurance Company (FDIC), the Office of the Comptroller of the Currency (OCC) and the Federal Reserve Board - is examined, it shows that indicators of monetary
} 
Schoenmaker (1993 and 1995) and Di Giorgio and Di Noia (1999) corroborates this point.

The question is therefore whether central banks should use its monetary policy instruments to cope with a systemic crisis. We have already argued that LOLR models showed that central banks should inject liquidity. Should central banks also intervene by changing the interest rate target? Several contributions indicate why this may be the case, as a systemic crisis may affect the well functioning of the interbank market. The interbank market allows banks to cope with their idiosyncratic liquidity shocks provided the aggregate supply and demand for liquidity match. Still, in general, the central bank will have to intervene to make up for the supply-demand mismatch, as the inelasticity of demand and supply will not allow interest rates to adjust so that the market clears. So, given the inelasticity, the central bank open market interest rate will determine the amount of transfers from liquidity short to liquidity long banks. At the same time, the expectations on the central bank intervention and interest rate policy will affect the banks ex ante investment in liquid assets: the higher the interbank market interest rates, the higher the amount banks will invest in liquid assets and the lower the need for central bank liquidity injection. (See Allen, Carletti and Gale (2009) and Freixas, Martin and Skeie (2009))

\subsection{Theory and practice of the lender of last resort}

The theory of the lender of last resort provides only a partial basis for the practical implementation of a specific policy, first, because different models emphasize different dimensions of the issue at stake and, second, because these models are necessarily based on a number of simplifying assumptions. Still, the different models seem to provide a consistent synthetic view of the lender of last resort based on the following principles. The lender of last resort facility should allow to:

- Lend against collateral to inject the required amount of aggregate liquidity

- Purchase assets to avoid an illiquidity/insolvency spiral

- Provide loans directly to solvent illiquid institutions if the interbank market is not operating properly

- If a bank is liquidated, provide liquidity to those banks that are connected through the network of interbank loans.

policy do affect actions of the Federal Reserve Board, while it does not affect those of the FDIC or the OCC. 
Lender of last resort models usually considers only one class of assets. The extension to several assets seems, nevertheless a simple exercise in cost-benefit analysis.

The possible choice of collateral and assets to be purchased would presumably extend in the following way:

- When confronted with different assets, the central bank will choose as collateral those assets that provide the maximum liquidity at the lowest cost (or at the lowest risk).

- The central bank should buy assets in those markets where fire sales and cashin-the-market result in undervalued assets.

It is interesting to analyse to what extent the central banks behaviour during the current crisis has been guided by these broad theoretical principles of the lender of last resort.

The ECB has lent repo on a short term basis against a wide class of financial assets ${ }^{9}$. After that date it started to buy covered bonds. By resorting mainly to repo operations, it has followed what we have referred to as the macroeconomic approach. As a consequence, our assessment of its policy depends on whether we consider its definition of "eligible collateral" was too wide or too narrow. The European banks in financial distress were not in trouble because of lack of liquidity but because of the quality of the assets they held, so that the eligible collateral did not seem to be too narrow. The issue was rather whether it was too wide. Of course, anecdotal evidence of Australian securitized loans being used as collateral is clearly insufficient, as these assets can be held in the portfolio of a bank in the Euro area. One interesting piece of evidence is given by the a number of banks (Crédit Agricole, UBS, RBS and Lloyds) that have been buying back their subordinated debt that was trading at a discount on par value ( $28 \%$ for Crédit Agricole). The banks used their liquidity to buy back its longer term bonds and by so doing immediately booked an accounting profit and replace the market discipline that originated the discount by the easier short term funding. The question is therefore whether it is efficient for the Swiss National Bank, the ECB and the Bank of England to finance the restructuring of banks' liabilities and the replacement of stable long term liabilities by short term ones. If central banks are in fact subsidizing commercial banks, by providing them with cheaper resources than the ones they would obtain in the market this is clearly an inefficient. On the other hand, the alternative, favourable, interpretation is simply that central banks are providing liquidity successfully and that these banks have all the resources they need to cope with the progressive withdrawal of liquidity that is to come, so the operation simply demonstrates how successful the liquidity

\footnotetext{
${ }^{9}$ Until its decision of May $2007^{\text {th }}$, it has not bought assets from the banks.
} 
injection by central banks has been. Still, the pure macroeconomic approach may be questioned on the basis of this possible implicit generalized funding subsidy.

The Federal Reserve has also resorted to liquidity injection, but its implementation has been quite different. First, although the auctioning of "toxic assets" could not in the end be implemented, the Fed has resorted to buying assets (although obviously not the toxic ones!). Also, it has created special refinancing facilities. So, the Fed approach combines the macroeconomic and the network approach to the lender of last resort. It is true that the discount window, although available to all banks, has not been a key element in the Fed interventions because borrowing from the discount window suffers from a "stigma effect", as banks view their use of the discount window as damaging their reputation. Still, different types of financial institutions (primary dealers, mutual funds...) have had access to different facilities. By so doing the Federal Reserve has created a substitute to the interbank market and taken into account the crucial impact of network effects in the contagion phenomenon.

\section{CONCLUSION}

The overall conclusion is that central banks in developed countries have been successful in avoiding the worst consequences of the crisis. By abandoning the separation between prudential regulation and monetary policy central banks have adopted a hand on approach and quickly reacted to the financial institutions' liquidity needs. Have they gone too far in injecting liquidity? The cost benefit analysis clearly weights in quite an asymmetric way the cost of the two types of errors. Injecting too much liquidity has a limited cost in terms of possible implicit subsidies to the banking industry. Injecting an insufficient amount is useless fosters contagion and may lead to having to inject even more liquidity, as illustrated in the Acharya and Yorulmazer (2006) model. So, the initial move to inject as much liquidity as needed by banks (as illustrated in particular by the ECB full allotment procedures) was the right one. The cost to taxpayers might be high ${ }^{10}$ but clearly lower than the cost of a complete banking meltdown. In the future we will see how central banks progressively withdraw the

\footnotetext{
${ }^{10}$ As of today the Treasury has made profits on both its capital injections in Citigroup and its loans to financial institutions.
} 
liquidity they have injected and restore their inflation targeting policy. This will be a test for banking institutions resiliency and will mark the conclusion of the current banking crisis.

\section{REFERENCES}

Acharya, V. and Yorulmazer, T. (2007). "Cash-in-the-market pricing and optimal resolution of bank failures". Review of Financial Studies, forthcoming.

Allen, Franklin and Douglas Gale (1994). "Limited Market Participation and Volatility of Asset Prices". American Economic Review, 84, 933-955.

Allen, Franklin and Douglas Gale (1998). "Optimal Financial Crises". Journal of Finance, 53, 1245-1284.

Allen, Franklin and Douglas Gale (2000). "Financial Contagion." The Journal of Political Economy, Vol. 108, No. 1, pp. 1-33.

Brunnermeier, Markus, Andrew Crockett, Charles Goodhart, Avinash D. Persaud, Hyun Shin (2009)." The Fundamental Principles of Financial Regulation". Geneva Reports on the World Economy 11, International Center for Monetary and Banking Studies (ICMB).

Brunnermeier, M. and L. Pedersen. "Market Liquidity and Funding Liquidity". Journal of Finance.

Bagehot, W. (1873). "Lombard Street: A Description of the Money Market". London: H.S. King.

Calomiris, C.W. and Kahn, C. M. (1991). "The Role of Demandable Debt in Structuring Optimal Banking Arrangements". American Economic Review 81, 497-513.

Carlsson, Hans and Eric Van Damme (1993). "Global Games and Equilibrium Selection”. Econometrica, 61(5), pp. 989-1018.

Chari, V. and R. Jagannathan. (1988). "Banking panics, information and rational expectations equilibrium". Journal of Finance 43(3):749-61.

Di Giorgio G. and Di Noia (1999). "Should Banking Supervision and Monetary Policy Tasks be given to Different Agencies?" International Finance, vol. 2(3), pages 361-78, November.

Freixas, X., and Rochet, J-C. (2007), "Microeconomics of Banking”, second edition, MIT press.

Freixas, X., Parigi, B.M. and Rochet, J-C. (2000). "Systemic Risk, Interbank Relations and Liquidity Provision by the Central Bank", Journal of Money, Credit and Banking. August, 32, Part 2, 611-638. 
Freixas, X., Parigi, B.M. and Rochet, J-C. (2004). "The Lender of Last Resort: A $21^{\text {st }}$ Century Approach", Journal of the European Economic Association, 2, 1085-1115.

Freixas, X. and Jorge, J. (2008). "The role of Interbank Markets in Monetary Policy: A model with rationing", Journal of Money, Credit and Banking, 40, 1151-1176.

Freixas, X. and Holthausen, C. (2005).'Interbank Market Integration under Asymmetric Information”, Review of Financial Studies, 18, 459-490.

Freixas, X., A. Martin and D. Skeie, 2009. "Bank liquidity, interbank markets, and monetary policy". Staff Reports 371, Federal Reserve Bank of New York.

Friedman, M., and A. Schwartz. (1963). "A monetary history of the United States, 1867-1960", Princeton, N.J.: Princeton University Press.

Gertler, M. and P. Karadi (2009)"A model of Unconventional Monetary Policy "Mimeo, New York University.

Goldstein, I. and Pauzner, A. (2005). "Demand Deposit Contracts and the Probability of Bank Runs”, Journal of Finance, 60, 1293-1327.

Goodfriend, M. and King, R. (1988). "Financial Deregulation Monetary Policy and Central Banking" in W. Haraf and Kushmeider, R. M. (eds.) Restructuring Banking and Financial Services in America, AEI Studies, 481, Lanham, Md.: UPA.

Heider, F., M. Hoerova and C. Holthausen (2009) "Liquidity Hoarding and Interbank Market Spreads: the role of counterparty risk". $W p, E C B$.

Goodhart C. and D. Shoenmaker, Humphrey, D.B., (1986). "Payments Finality and risk of settlement failure" in: Saunders, A., White, L. (eds.), Technology and the Regulation of Financial Markets: Securities, Futures, and Banking. Lexington, MA: Lexington Books.

Humphrey, T. (1989). "The Lender of Last Resort: The Concept in History". Federal Reserve Bank of Richmond Economic Review, 75, 8-16.

Ioannidou, V. P. (2005). "Does monetary policy affect the central bank's role in bank supervision?". Journal of Financial Intermediation, 14, 58-85.

Iyer, R. and Peydro, J.L. (2006). "Interbank Contagion: Evidence from Real Transactions". University of Amsterdam, mimeo.

Kahn, C. M. and Santos, J. A. C. (2005). "Allocating bank regulatory powers: Lender of last resort, deposit insurance and supervision". European Economic Review, 49, 21072136.

Kahn, C. M. and Santos, J. A. C. (2006). "Who Should Act as Lender of Last Resort? An Incomplete Contracts Model: A Comment". Journal of Money Credit and Banking, 38, 1111-1118. 
Kyotaki, N. and Moore, J. (1997). “Credit Cycles”. Journal of Political Economy, 105, 211-248.

Lacker, J.M. (2004). "Payment system disruptions and the Federal Reserve following". September 11, 2001, Journal of Monetary Economics, 51, 935-965.

Lehar, A. (2005). "Measuring systemic risk: A risk management approach". Journal of Banking and Finance, 29, 2577-2603.

Leitner, Y. (2005). "Financial Network: Contagion, Commitment, and Private Sector Bailouts". Journal of Finance, 60, 2925-2953.

Lucas, R. E. (2008). "Bernanke is the Best Stimulus Right Now", The Wall Street Journal, December 23.

Lybeck, T. and Morris, J.A. (2004). "Central Bank Governance: A survey of Boards and Management". IMF Working Paper 04/226.

Merton, R.C. (1977). "An analytic derivation of the cost of deposit insurance and loan guarantees: An application of modern option pricing theory". Journal of Banking and Finance, 1, 3-11.

McAndrews, J. and Potter, S. (2002). "Liquidity Effects of the Events of September 11", 2001. Federal Reserve Banks of New York Economic Policy Review, November, $59-79$.

Mistrulli, P. (2005). "Interbank lending patterns and Financial Contagion". Bank of Italy, mimeo.

Morris, S. and Shin H. S. (1998). "Unique Equilibrium in a Model of Self-fulfilling Currency Attacks". American Economic Review, 88, 587-597.

Peek, J., Rosengren, E. and Tootell, G. (1999). "Is Bank Supervision Central to Central Banking”. Quarterly Journal of Economics, 114, 629-653.

Peltzman, S. (1976). “Toward a More General Theory or Regulation”, Journal of Law and Economics, 19, 211-40.

Repullo, R. (2000). "Who should act as a Lender of Last Resort? An Incomplete Contract model", Journal of Money, Credit and Banking, 32, 580-605.

Rochet, J-C. and Vives, X. (2004). "Coordination Failures and the Lender of Last Resort: Was Bagehot Right After All?". Journal of the European Economics Association, 2, 1116-1147.

Santos, J.A.C. (2006). "Insuring Banks against Liquidity Shocks: The Role of Deposit Insurance and Lending of Last Resort". Journal of Economic Surveys, 20, 459-482. 
Schnabel, I. and Shin, H.S. (2004). "Liquidity and Contagion: the Crisis of 1763". Journal of the European Economic Association, 2, 929-968.

Shin, H.S. (2006). "Risk and liquidity in a system context". Bank of international settlements Working Paper N. 212.

Sprague, O.M.W. (1910). "History of Crises under the National Banking System", Philadelphia: Govt. Print. Off.

Stigler, G.J. (1971). "The Theory of Economic Regulation". The Bell Journal of Economics and Management Science, 2, 3-21.

Timberlake, R.H. (1978).'The Origins of Central Banking in the United States". Cambridge, Mass: Harvard University Press.

Timberlake, R.H. (1993). "Monetary Policy in the United States". Chicago: University of Chicago Press.

Thornton, H. (1802). "An Enquiry into the Nature and Effects of the Paper Credit of Great Britain”. London: Hatchard.

Trichet, J.C. " The financial crisis and our response so far-Conference". Chatham House Global Financial Forum, New York, 27 April 2009.

Upper, C. and Worms, A. (2004). "Estimating Bilateral exposures in the German interbank market: Is there a danger of contagion?". European Economic Review, 48, 827-849.

Wells, S. (2004). "Financial interlink ages in the United Kingdom's interbank market and the risk of contagion". Bank of England, Working Paper 230.

White, E.N. (1983). "The Regulation and Reform of the American Banking System, 1900-1929”. Princeton, NJ: Princeton University Press. 